\title{
Empirical Analysis on the Measurement of Rural Financial Ecological Environment in Jilin Province
}

\author{
Chunhui Wang ${ }^{\mathrm{a} .}$, Nan $\mathrm{Wu}^{\mathrm{b}}$ \\ Finance School \\ Changchun University of Finance and Economics, CCUFE \\ Changchun, China \\ ${ }^{\mathrm{a}}$ Email: 262142194@qq.com, ${ }^{\mathrm{b}}$ Email: wangchunhui920@126.com
}

\begin{abstract}
Financial ecological environment has become an important system which is used to measure the economic development level of a country or region. However, it is so vital that concerning about the rural economy and its reasonable development in the critical period of transformation. This paper, in which using factor analysis, measured and ranked the rural financial ecological environment of nine cities in Jilin province from 2015 to 2016 and analyzed the measurement results and put forward improvement suggestions. At the same time, it was hoped that this way could be used to measure the rural financial ecological environment regularly with expanding the measuring range and adding the measurement index, which taken as the normalized measurement index and the indicator of economic development.
\end{abstract}

Keywords: Rural financial ecological environment; principal component analysis method,; Jilin province; Empirical analysis

\section{INTRODUCTION}

Financial ecosystem was first put forward by the Central bank governor, Xiaochuan Zhou in 2004, with a bionic ecology in ecological system. He suggested that this method should be introduced into the financial sector to solve problems on account of financial system resembled to ecological system, there related between each subsystem; NuojinXu (2005) analyzed the problems and solutions of the entire financial system from an ecological perspective. Yang Li (2005) stated that its constituent elements from the perspective of China's urban financial ecological environment, with getting the scores of each city for ranking using data envelopment analysis. Qingtian $\mathrm{Wu}$ (2012) studied the relationship between rural financial ecological environment and financial efficiency, using BP artificial neural network, and put forward the optimized path. Maohai Huang (2016) measured the urban financial ecological environment of Fujian province and put forward optimization countermeasures through principal components.

According to the previous research results, this paper thought that the rural financial ecological environment was referred to the sum of external and internal factors, which were related to the survival and development of rural financial subjects in a certain period of time.

\section{INDEX OF MEASURING RURAL FINANCIAL ECOLOGICAL ENVIRONMENT}

The coordinated development of various subsystems was of vital importance since the financial system was regarded as a bionic ecosystem, the transformation was the same as the urbanization and modernization of the rural, which needed good internal and external environment. According to the index about measuring Chinese city financial ecology environment by the academy of social sciences financial research institute, the paper selected index as shown in table 1 .

This index system was divided into four first-level index, including economic basis, financial efficiency, government intervention and protection, social and cultural environment, both the external environment of financial main body, also internal environment;18 secondary index were to be carried out according to the features of primary index selection, but not all, lacking of the data about integrity, the law, the index of which would be investigated and kept secret to choose alternative index. Of course, these excluded data did not have a material impact on the results.

\section{EMPRICAL ANALYSIS PROCESS}

This paper was to measure the rural financial ecological environment of Jilin province using factor analysis method. The analysis process was as follows:

\section{A. Data}

Rural data of thirty-nine counties under the jurisdiction of nine cities in Jilin province in 2015 and 2016 were selected, excluding relevant data of primary industries in all districts of the city. The data was derived from the Jilin provincial statistical yearbook and the statistical bulletins on the national economic and social development of cities. The data in 2015 was as the first stage, then measured 2016 rural financial ecological environment according to this method, and the form of index was the relative abundance so as to compare with each city.

Eighteen secondary index data in 2015 was collected and calculated, the results were as Table 2 .

According to the test results in table 2, Cronbach 's Alpha $=0.971, \mathrm{KMO}=0.813>0.5$, it was stated that there had the strong correlation between the secondary index, and the probability was 0.000 less than the significance level, rejecting the null hypothesis that there was a significant difference with the unit matrix, instructions for factor analysis.

\section{B. Principal Component Analysis Process}

This paper measured the county-level rural data of nine 
cities in Jilin province using Spss17.0 software.

First, the test results as shown in table 3 , six factors were extracted, of which weights $0.29117,0.18518$,
$0.15875,0.1363,0.10174,0.8043$ on the basis of the cumulative variance contribution rate amounted to more than $85 \%$ (this data was calculated as $95 \%$ ).

\section{TABLE1.INDEX SYSTEM OF RURAL FINANCIAL ECOLOGICAL ENVIRONMENT MEASUREMENT IN JILIN PROVINCE}

\begin{tabular}{|c|c|}
\hline Level index & The secondary index \\
\hline The economic base & $\begin{array}{l}\mathrm{X}_{1:} \text { Per capita net income gap between urban and rural residents (per capita urban disposable } \\
\text { income-per capita rural disposable income/per capita rural disposable income) } \\
\mathrm{X}_{2:} \text { The level of agricultural modernization (The ratio of areas of machine-cultivated } \\
\& \text { machine-harvested \&machine-planted farmland) } \\
\mathrm{X}_{3:} \text { The ratio of rural GDP to provincial GDP } \\
\mathrm{X}_{4} \text { : The retail ratio of social consumer goods } \\
\mathrm{X}_{5:} \text { The ratio of output value of primary industry to total output value of province } \\
\mathrm{X}_{6} \text { : The ratio of the added value of township enterprises to rural GDP }\end{array}$ \\
\hline The efficiency of finance & $\begin{array}{l}\mathrm{X}_{7:} \text { The ratio of rural loans to gross rural product } \\
\mathrm{X}_{8:} \text { The ratio of rural savings to loans }\end{array}$ \\
\hline $\begin{array}{l}\text { Government intervention } \\
\text { and social security }\end{array}$ & $\begin{array}{l}\mathrm{X}_{9:} \text { Growth rate of social security subsidies } \\
\mathrm{X}_{10} \text { New cooperative medical insurance rate } \\
\mathrm{X}_{11:} \text { The growth rate of subsistence allowances for rural residents } \\
\mathrm{X}_{12:} \text { The rate of new rural social endowment insurance participation } \\
\mathrm{X}_{13} \text { The number of village committees per } 10,000 \text { people } \\
\mathrm{X}_{14: \text { Rural fiscal revenue gap }} \\
\mathrm{X}_{15:} \text { The ratio of rural fiscal revenue to rural GDP } \\
\mathrm{X}_{16:} \text { The ratio of rural education public expenditure to financial expenditure }\end{array}$ \\
\hline $\begin{array}{l}\text { The environment of Social } \\
\text { culture }\end{array}$ & $\begin{array}{l}\mathrm{X}_{17} \text { The ratio of number of full-time teachers to total number of teachers in rural primary schools, } \\
\text { middle schools and high schools } \\
\mathrm{X}_{18 \text { : }} \text { The ratio of rural population to total population) }\end{array}$ \\
\hline
\end{tabular}

TABLE 2.TEST RESULTS OF JILIN PROVINCE RURAL FINANCIAL ECOLOGICAL ENVIRONMENT IN 2015

\begin{tabular}{|c|c|c|c|c|}
\hline \multicolumn{2}{|c|}{ Reliability statistic } & \multicolumn{3}{|c|}{ KMO and Bartlett tests } \\
\hline \multirow{2}{*}{ Cronbach's Alpha } & Number & & $\begin{array}{c}\text { The Kaiser meyer-olkin measure of } \\
\text { sample adequacy }\end{array}$ & 0.813 \\
\hline \multirow{2}{*}{0.971} & \multirow{2}{*}{9} & $\begin{array}{c}\text { Bartlett's } \\
\text { sphericity test }\end{array}$ & The approximate chi-square & 545.903 \\
\cline { 4 - 5 } & & & df & 36 \\
\hline
\end{tabular}

TABLE 3.THE TOTAL VARIANCE EXPLAINED

\begin{tabular}{|c|c|c|c|c|c|c|c|c|c|}
\hline \multirow[b]{2}{*}{ Ingredients } & \multicolumn{3}{|c|}{ Initial eigenvalue } & \multicolumn{3}{|c|}{ Extract the squares and load } & \multicolumn{3}{|c|}{ Rotate the sum of squares and load } \\
\hline & $\begin{array}{c}\text { A } \\
\text { combined } \\
\end{array}$ & $\begin{array}{l}\% \text { of the } \\
\text { variance }\end{array}$ & Cumulative \% & $\begin{array}{c}\text { A } \\
\text { combined } \\
\end{array}$ & $\begin{array}{l}\% \text { of the } \\
\text { variance }\end{array}$ & Cumulative \% & $\begin{array}{c}\text { A } \\
\text { combined } \\
\end{array}$ & $\begin{array}{l}\% \text { of the } \\
\text { variance }\end{array}$ & Cumulative \% \\
\hline 1 & 7.022 & 39.010 & 39.010 & 7.022 & 39.010 & 39.010 & 5.241 & 29.117 & 29.117 \\
\hline 2 & 3.243 & 18.015 & 57.025 & 3.243 & 18.015 & 57.025 & 3.333 & 18.518 & 47.635 \\
\hline 3 & 2.521 & 14.003 & 71.029 & 2.521 & 14.003 & 71.029 & 2.858 & 15.875 & 63.510 \\
\hline 4 & 1.886 & 10.477 & 81.506 & 1.886 & 10.477 & 81.506 & 2.453 & 13.630 & 77.140 \\
\hline 5 & 1.315 & 7.305 & 88.811 & 1.315 & 7.305 & 88.811 & 1.831 & 10.174 & 87.314 \\
\hline 6 & 1.178 & 6.547 & 95.357 & 1.178 & 6.547 & 95.357 & 1.448 & 8.043 & 95.357 \\
\hline 7 & 611. & 3.394 & 98.752 & & & & & & \\
\hline 8 & 225. & 1.248 & 100.000 & & & & & & \\
\hline
\end{tabular}

Secondly, the scores of six factors of rural financial ecological environment of 9 cities in Jilin province can be obtained according to component score coefficient matrix, and then the formula was used:

$$
\mathrm{S}=\sum_{i=1}^{6} S_{i} \times \omega_{i}
$$

Equations. S-Composite scores for each city; 
$S_{i}$-the score of each factor from one to six $\omega_{i}$-the weight of each factor from one to six Composite scores of rural financial ecological environment of nine were shown in table 4 according to the formula and were ranked, with drawing the radar location map as shown in figure 1 .

TABLE 4.SCORES AND RANKING OF RURAL FINANCIAL ECOLOGICAL ENVIRONMENTAL FACTORS IN NINE CITIES OF JILIN PROVINCE IN 2015

\begin{tabular}{|c|c|c|c|c|c|c|c|c|}
\hline & Factor 1 & Factor 2 & Factor 3 & Factor of 4 & Factor of 5 & Factor 6 & $\begin{array}{l}\text { Composite } \\
\text { scores }\end{array}$ & Ranking \\
\hline Changchun & $\begin{array}{c}1.1901 \\
(1)^{\mathrm{a}} \\
\end{array}$ & $\begin{array}{c}1.0431 \\
(2)\end{array}$ & $\begin{array}{c}0.3321 \\
(6)\end{array}$ & $\begin{array}{c}1.0104 \\
(1)\end{array}$ & $\begin{array}{c}0.6300 \\
(7)\end{array}$ & $\begin{array}{c}0.9907 \\
(1)\end{array}$ & 0.6403 & 1 \\
\hline Yanbian & $\begin{array}{c}0.9812 \\
(8)\end{array}$ & $\begin{array}{c}0.9084 \\
\text { (3) }\end{array}$ & $\begin{array}{c}1.4955 \\
\text { (2) }\end{array}$ & $\begin{array}{c}0.1082 \\
(6)\end{array}$ & $\begin{array}{c}1.1891 \\
(2)\end{array}$ & $\begin{array}{c}0.3674 \\
\text { (4) }\end{array}$ & 0.2852 & 2 \\
\hline Siping & $\begin{array}{c}0.9709 \\
\text { (3) }\end{array}$ & $\begin{array}{c}0.1259 \\
(6)\end{array}$ & $\begin{array}{c}0.2654 \\
\text { (3) }\end{array}$ & $\begin{array}{c}0.3773 \\
\text { (3) }\end{array}$ & $\begin{array}{c}0.1162 \\
(5)\end{array}$ & $\begin{array}{c}2.3922 \\
\text { (9) }\end{array}$ & 0.1954 & 3 \\
\hline Songyuan & $\begin{array}{c}0.5176 \\
(4)\end{array}$ & $\begin{array}{l}1.0059 \\
(7)\end{array}$ & $\begin{array}{c}0.0672 \\
(4)\end{array}$ & $\begin{array}{c}1.0100 \\
(2)\end{array}$ & $\begin{array}{c}0.4116 \\
(6)\end{array}$ & $\begin{array}{c}0.9113 \\
(2)\end{array}$ & 0.1229 & 4 \\
\hline Tonghua & $\begin{array}{c}0.4295 \\
(6)\end{array}$ & $\begin{array}{c}1.2332 \\
(1)\end{array}$ & $\begin{array}{c}0.2115 \\
(5)\end{array}$ & $\begin{array}{c}0.1304 \\
(5)\end{array}$ & $\begin{array}{c}0.3822 \\
(3)\end{array}$ & $\begin{array}{c}0.0722 \\
(7)\end{array}$ & 0.1206 & 5 \\
\hline Jilin & $\begin{array}{c}0.9836 \\
(2)\end{array}$ & $\begin{array}{c}0.1704 \\
(4)\end{array}$ & $\begin{array}{c}0.1493 \\
(7)\end{array}$ & $\begin{array}{c}2.3868 \\
(9) \\
\end{array}$ & $\begin{array}{c}0.1066 \\
(4)\end{array}$ & $\begin{array}{c}0.4618 \\
(3)\end{array}$ & 0.0048 & 6 \\
\hline Liaoyuan & $\begin{array}{c}0.0681 \\
(5)\end{array}$ & $\begin{array}{c}1.2333 \\
(8)\end{array}$ & $\begin{array}{c}1.2283 \\
(8)\end{array}$ & $\begin{array}{c}0.1334 \\
\text { (4) }\end{array}$ & $\begin{array}{c}1.8516 \\
(1)\end{array}$ & $\begin{array}{c}0.0036 \\
(6)\end{array}$ & 0.2369 & 7 \\
\hline Baicheng & $\begin{array}{c}0.4321 \\
\text { (7) }\end{array}$ & $\begin{array}{c}1.4011 \\
(9)\end{array}$ & $\begin{array}{c}1.5238 \\
(1)\end{array}$ & $\begin{array}{c}0.1843 \\
(7)\end{array}$ & $\begin{array}{c}0.8664 \\
(8)\end{array}$ & $\begin{array}{c}0.0651 \\
(5)\end{array}$ & 0.2514 & 8 \\
\hline Baishan & $\begin{array}{c}1.7513 \\
(9)\end{array}$ & $\begin{array}{c}0.1593 \\
(5)\end{array}$ & $\begin{array}{c}1.2964 \\
(9)\end{array}$ & $\begin{array}{c}0.1986 \\
(8)\end{array}$ & $\begin{array}{c}1.2922 \\
(9)\end{array}$ & $\begin{array}{c}0.3284 \\
(8)\end{array}$ & 0.8712 & 9 \\
\hline
\end{tabular}
cities

${ }^{a}$ The number of each factor score in the brackets was its ranking status. For example, (1) under factor 1 of Changchun city indicated that factor 1 of Changchun city ranked first among nine

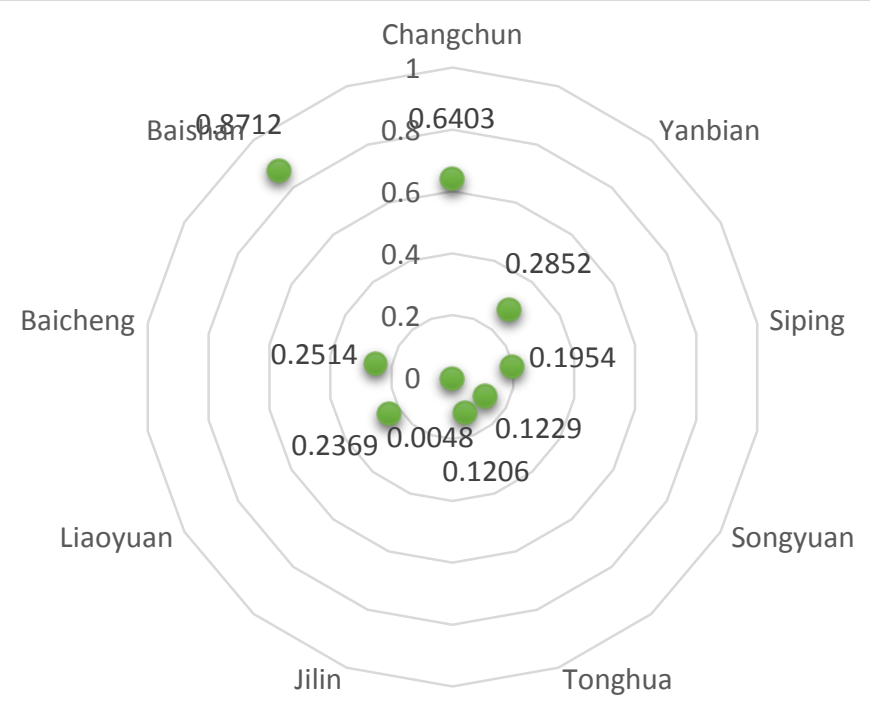

Fig. 1 Radar map of the comprehensive scores of rural financial ecological environment in 9 cities of Jilin province in 2015

Thirdly, according to the rotating component matrix, it can be seen that:

Factor 1 contains $\mathrm{X}_{5}, \mathrm{X}_{10}, \mathrm{X}_{13}, \mathrm{X}_{15}, \mathrm{X}_{16}, \mathrm{X}_{18}$ These secondary index involved government intervention and guarantee factors.

Factor 2 included $\mathrm{X}_{6}, \mathrm{X}_{8}, \mathrm{X}_{14}, \mathrm{X}_{15}, \mathrm{X}_{17}$.the economic and social cultural factors involved in these secondary index;

Factor 3 includes $X_{1}, X_{2}, X_{7}$.These secondary index involve economic and financial factors.

Factor 4 includes $\mathrm{X}_{4}, \mathrm{X}_{9}, \mathrm{X}_{11}$. These secondary index involve economic factors.

Factor 5 and factor 6 had a small proportion, and each factor contained only one secondary index, which was government guarantee $\mathrm{X}_{12}$ and economic base $\mathrm{X}_{3}$ index respectively.

From the above results, the government's intervention and protection were more important for the rural financial ecological environment, the economic and financial environment was second, then on the role of social cultural environment. It was consistent with the actual that the rural government role was particularly important due to the restriction of the various conditions, it also suggested that the government's as the good security safeguard was good for the rural financial ecological environment, which was different from the urban financial ecological environment or which factor 1 was usually the cause of the economic factor. 
According to such methods and steps, the rural financial ecological environment of Jilin province will be

ranked again in 2016 (table 5)

TABLE 5.SCORES AND RANKING OF RURAL FINANCIAL ECOLOGICAL ENVIRONMENTAL FACTORS IN NINE CITIES OF JILIN PROVINCE IN $2016^{\mathrm{b}}$

\begin{tabular}{|c|c|c|c|c|c|c|}
\hline & Factor 1 & Factor 2 & Factor 3 & Factor of 4 & $\begin{array}{c}\text { Composite } \\
\text { scores }\end{array}$ & Ranking \\
\hline Yanbian & $\begin{array}{l}0.3598 \\
(5)\end{array}$ & $\begin{array}{l}1.2084 \\
(2)\end{array}$ & $\begin{array}{l}1.6409 \\
(1)\end{array}$ & $\begin{array}{c}1.2752 \\
(8)\end{array}$ & 0.5099 & 1 \\
\hline Changchun & $\begin{array}{c}1.1469 \\
(1)\end{array}$ & $\begin{array}{c}0.1261 \\
(5)\end{array}$ & $\begin{array}{c}0.4616 \\
(6)\end{array}$ & $\begin{array}{c}0.9692 \\
(1) \\
\end{array}$ & 0.4127 & 2 \\
\hline Tonghua & $\begin{array}{c}0.1385 \\
(6)\end{array}$ & $\begin{array}{c}1.5127 \\
(1)\end{array}$ & $\begin{array}{c}0.3113 \\
\text { (4) }\end{array}$ & $\begin{array}{c}0.1873 \\
(6)\end{array}$ & 0.2840 & 3 \\
\hline Jilin & $\begin{array}{c}0.8142 \\
(2)\end{array}$ & $\begin{array}{c}0.4844 \\
(4)\end{array}$ & $\begin{array}{c}0.9392 \\
(8)\end{array}$ & $\begin{array}{c}0.2317 \\
(7)\end{array}$ & 0.1897 & 4 \\
\hline Siping & 0.6109 (3) & $\begin{array}{l}0.5950 \\
(6)\end{array}$ & $0.3416(5)$ & $\begin{array}{l}0.4506 \\
\text { (4) }\end{array}$ & 0.1882 & 5 \\
\hline Songyuan & $\begin{array}{l}0.5377 \\
\text { (4) }\end{array}$ & $\begin{array}{l}0.7101 \\
(7)\end{array}$ & $\begin{array}{l}0.0297 \\
(3)\end{array}$ & $\begin{array}{c}0.7513 \\
\text { (3) }\end{array}$ & 0.1148 & 6 \\
\hline Baicheng & $0.8695(8)$ & $\begin{array}{l}1.2011 \\
(9)\end{array}$ & $\begin{array}{l}1.5275 \\
(2)\end{array}$ & $\begin{array}{c}0.3664 \\
(5)\end{array}$ & 0.2555 & 7 \\
\hline Baishan & $\begin{array}{l}2.0750 \\
(9)\end{array}$ & $\begin{array}{l}0.5897 \\
(3)\end{array}$ & $\begin{array}{c}0.6589 \\
(7)\end{array}$ & $\begin{array}{l}0.7518 \\
(2)\end{array}$ & 0.5622 & 8 \\
\hline Liaoyuan & $\begin{array}{c}0.3866 \\
(7)\end{array}$ & $\begin{array}{c}1.1629 \\
(8)\end{array}$ & $\begin{array}{c}1.1093 \\
(9)\end{array}$ & $\begin{array}{l}1.9695 \\
(9)\end{array}$ & 0.8816 & 9 \\
\hline
\end{tabular}

${ }^{b}$ It can be observed that four factors only could be extracted from the data in 2016, due to lacking of the added value of township enterprises in the 2016 index data. Factor 1 in the two-year ranking was the factor of government intervention and guarantee, which conformed to the objective law.

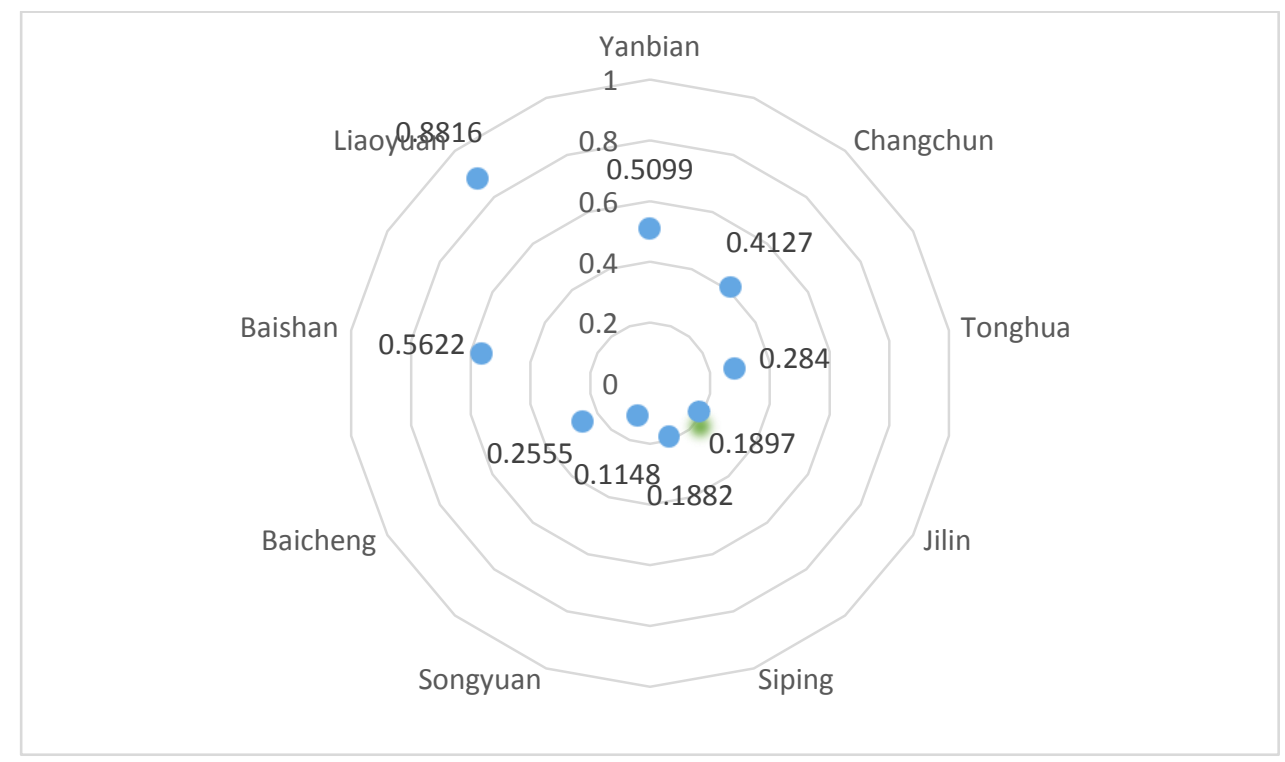

Fig. 2. Radar map of the comprehensive score of rural financial ecological environment in 9 cities of Jilin province in 2016

\section{Result}

According to data observation, in 2015, Changchun was the first city, with a large financial input, a high degree of social security and a good economic and financial environment. Yanbian ranked second in the list. There was a large gap between the two cities. Siping and Songyuan were similar in overall level, which were a grain production bases. The rank of Tonghua, Jilin and Liaoyuan rooted in the difference between government involvement and economic foundation. Baicheng and Baishan, the last two, mainly were restricted with the natural conditions, the relatively low level of agricultural modernization in the countryside, due to fiscal investment less focused on the villages and towns, but more the development of the secondary industry and tertiary industry.

The period of Jilin province's rural economy transformation in 2016 was the early stage. Land circulation, the establishment of rural cooperative and the Marketization of food price had begun, which seemed to be a "reshuffle" of resources for the rural market. The redistribution of various resources was the key to the scores of rural financial ecological environment. The ranking of rural financial ecological environment in 2016 , Yanbian surpassed Changchun to become the first place, but the difference was not large. The advantage of Yanbian lied in the increased financial investment. Tonghua and 
Jilin ranked up one place respectively. Jilin's financial investment had always been high, while Tonghua's social security was high. Siping and Songyuan went down one place respectively, as the two food bases, the rural economy development needed more financial input and safeguard strength, and it was normal that there were some volatilities during the transitional period. Baishan and Baicheng did not change much. Liao yuan fell last, its social security expenditure showed negative growth, which was crucial to the rank.

IV. COUNTERMENASURE TO IMPROCE RURAL FINANCIAL ECOLOGICAL ENVIRONMENT IN JILIN PROVINCE

\section{A. Continue to Increase Government Input and Safeguard Efforts}

From empirical analysis process and existing literature research basis, environmental economic foundation was the most important index impacted on the urban financial ecological environment, but the government's investment and guarantee was mainly the index that impacted on rural financial ecological environment quality, including full of policy and funding support. Continuing to increase financial investment and social security was the foundation for rural development.

\section{B. Fully Guarantee the Standard and Quality of Peasants' Lives after Land Transfer}

The new socialist countryside, rural urbanization and the circulation of land management modes were all new policies for the development of agriculture and the signs of agricultural modernization. However, these new policies must ultimately ensure the improvement of the quality of life of farmers after their lifestyle changes. Food prices in recent years, of Jilin province, particularly corn prices, Marketization reversed the transmission of rural life way, farmers' psychological acceptance and source of income to be fundamentally solved, otherwise, the so-called agricultural modernization would become a mere formality.

\section{Improve the Social and Cultural Level of Farmers}

There was a rural "empty nest" phenomenon in Jilin province countryside, namely the farmers' children have received a higher education level and far from home, farming idle house, aging population, dropped labor ratio, which was the reason of land circulation and the modernization of agriculture. For example, the change of traditional family corn cultivation, the development of facility agriculture, and the modernization of farm required high level of professional talents. Therefore, farmers in the future will be high quality professional and technical talents.

With economic transition, rural economic development in Jilin province was in the critical period, the influences of the ecological environment with a series of reform on financial should be noticed. This paper thought, it should make the rural financial ecological environment measure normalized with continuing to expand the measuring range, increasing measuring index, which was helpful for each city to distribute reasonably existing resources.

\section{Improve the Rural Credit Evaluation System}

As a reflection of personality, credit capital was more and more important. At present, rural informal finance was much larger than formal finance, so the data obtained from financial institutions cannot cover the overall level of credit and needed to be comprehensively evaluated through non-financial data. Above mentioned, the data of rural credit field needed to be investigated. If there was as well as urban credit system, the study would directly obtain the relevant data to facilitate the research. Therefore, it was particularly important to improve the evaluation credit system to measure and evaluate the financial ecological environment.

\section{ACKNOWLEDGMENT}

This paper was stage result of Jilin provincial education department "13th five-year" social science project < Research on measurement of rural financial ecological environment of Jilin province> (Contract No. JJKH20181355SK)

\section{REFERENCES}

[1] Li Yang. Wang gang. Liu yuhui. Evaluation of China's urban financial ecological environment [M], people's publishing house, November 1, 2005.

[2] Wu qingtian. Research on optimization of rural financial ecological environment from the perspective of financial efficiency [M], economic science press, February 1, 2012.

[3] Wang guogang. Feng guanghua. Evaluation of financial ecological environment in China [M]. Social science literature publishing house, May 1, 2015.

[4] Huang maohai et al. Evaluation study on financial ecological environment measurement of Fujian province based on principal component analysis [J], Fujian BBS humanities and social science edition, May 2016. 